\title{
Correction to: Comparison of renal region, cerebral and peripheral oxygenation for predicting postoperative renal impairment after CABG
} llonka N. de Keijzer ${ }^{1} \mathbb{(} \cdot$ Marieke Poterman
Thomas W. L. Acheeren ${ }^{1}(\mathbb{D})$

Published online: 16 December 2021

(c) Springer Nature B.V. 2021

\section{Correction to: \\ Journal of Clinical Monitoring and Computing https://doi.org/10.1007/s10877-021-00701-4}

In the original publication of the article, the $95 \%$ CI of peripheral tissue oxygenation decrease $>10 \%$ from baseline was published incorrectly under Abstract section. The correct CI should read as $95 \%$ CI 0.619 to $0.914 ; \mathrm{p}=0.010$.

Publisher's Note Springer Nature remains neutral with regard to jurisdictional claims in published maps and institutional affiliations.

The original article can be found online at https://doi.org/10.1007/ s10877-021-00701-4.

Ilonka N. de Keijzer

i.n.de.keijzer@umcg.nl

1 Department of Anaesthesiology, University Medical Centre Groningen, Hanzeplein 1, Groningen 9713 GZ, The Netherlands

2 Department of Cardiothoracic Surgery, University Medical Centre Groningen, Groningen, The Netherlands 